\title{
Covf: $121109-.7$
}

$\frac{\text { PROGRESS IN THE DEVELOPMENT OF CURIUM-244 }}{\text { RADIOTSOTOPIC POWER FUEL } *}$

R. E. McHenry and T. A. Butler

Isotopes Development Center

Oak Ridge National Laboratory

Post Office Box X

Oak Ridge, Tennessee 37830

Curium-244 is being developed to provide a reliable source of thermal energy that can be converted to electrical power by several conversion systems.

Curium has been chosen as a power fuel for several reasons:

(1) high power density, (2) excellene properties of fuel compound,

(3) low cost, and (4) availability. Curium sesquioxide $\left(\mathrm{Cn}_{2} \mathrm{O}_{3}\right)$

has been chosen as tine primary curium fuel form for heat source

-applications because of its thermal stability and its compatibility

with high temperature resistant encapsulating materials. The high melting point $\left(2265^{\circ} \mathrm{C}\right)$ and high power density of ${ }^{24}{ }^{4} \mathrm{Cm}_{2} \mathrm{O}_{3}\left(\sim 27 \mathrm{~W} / \mathrm{cm}^{3}\right)$ afford a flexible range of power converter applications, including thermoelectric, thermodynamic cycle, and thermionic generators.

Curium-244 will be available in large quantities (10-50 kg/yr) as a by-product of power reactor operation in the last half of the 1970 decade and will, therefore, bear no cost of reactor irradiation. Various estimates of the future price of curium-244 based on large quantity production have ranged from $\$ 30$ to $\$ 60 / W_{t}$ of unencapsulated

\footnotetext{
*Research sponsored by the U.S. Atomic Energy Commission under contract with the Union Carbide Corporation.
}

\section{NOTICE}

This report was prepared as an account of work sponsored by the United States Government. Neither the United States nor the United States Atomie Energy Commission, nor any of their employees, nor any of their contractors, subcontractors, or their employees, makes any warranty, express or implled, or assumes any legal tiability or responsibility for the accuracy, completeness or usefulness of any information, apparatus, product or process disclosed, or represents that its use product or process disclosed, or represents 
$\mathrm{Cm}_{2} \mathrm{O}_{3}$ powder. ${ }^{1}$ To the estimate of curium-244 fuel cost should be added an estimated $\$ 40 / W_{t}$ for encapsulation costs for sources containing about $2000 \mathrm{~W}_{t}$ to arrive at a cost of $\$ 100 / \mathrm{W}_{t}$ for an encapsulation source. It is estimated that encapsulated plutonium-238 heat sources will cost about $\$ 500 / \mathrm{W}_{t}$ in the future as compared to a present day $\$ 700 / \mathrm{w}_{\mathrm{t}}$.

The predicted cost of electrical power from isotope fueled systems makes these systems cost-effective in a number of aerospace applications and competitive with solar cells, particularly in low-earth orbit missions.

A summary of the status of the determination of those properties which are necessary to assure safety under several siruations is given in Table 1. Recent progress in the determination of the properties of ${ }^{244} \mathrm{Cm}_{2} \mathrm{O}_{3}$ include helium release, thermal conductivity, seawater leach rates, and vapor diffusion data.

The diffusion parameter $\left(D^{\prime}\right)$ of helium in ${ }^{244} \mathrm{Cm}_{2} \mathrm{O}_{3}$ where $D^{-}=D / a^{2}$

$D=$ effective diffusion coefficient, $\mathrm{cm}^{2} / \mathrm{sec}$, and $a=$ effective radius of releasing unit, $\mathrm{cm}$, was determined under steady-state conditions in the temperature range $900-1800^{\circ} \mathrm{C}$. In the temperature range $900-1620^{\circ} \mathrm{C}, \mathrm{D}^{-}$is the sum of Equations (1) and (2): 


$$
\begin{aligned}
& D^{-}=7.87 \times 10^{-4} \exp \left(-16,248 / \mathrm{RT}^{\circ} \mathrm{K}\right) \\
& \mathrm{D}^{-}=68.0 \exp \left(-53,080 / \mathrm{RT}^{\circ} \mathrm{K}\right)
\end{aligned}
$$

Above $1620^{\circ} \mathrm{C}, \mathrm{D}^{-}$is given by Equation (3):

$$
D^{-}=4.65 \times 10^{7} \exp \left(-102,780 / R^{\circ} \mathrm{K}\right)
$$

The thermal conductivity of ${ }^{24}{ }^{4} \mathrm{Cm}_{2} \mathrm{O}_{3}$ in the temperature range is given by Equation (4):

$$
1 / \mathrm{k}=37.795+0.01659 \mathrm{~T} \text {, }
$$

where $\mathrm{k}$ is in $\mathrm{W} / \mathrm{crm} \cdot{ }^{\circ} \mathrm{C}$ and $\mathrm{T}$ is in ${ }^{\circ} \mathrm{K}$.

The leach rate ( $\mathrm{S}, \mathrm{mg} /$ liter) of ${ }^{244} \mathrm{C}_{2} \mathrm{O}_{3}$ by seawater is given by Equation (5):

$$
s=9.06 \times 10^{-4} t^{1.913}
$$

where $t=t i m e, h r$.

The data on the vapor transport of ${ }^{244} \mathrm{Cm}_{2} \mathrm{O}_{3}$ through helium are given by Equation (6):

$$
\log _{10}\left[\frac{(D)(C)}{T^{1 / 2}} \times 10^{10}\right]=14.324-(29,050 / T),
$$

where $D=$ diffusion coefficient, $\mathrm{cm}^{2} / \mathrm{sec}$,

$$
\begin{aligned}
& \mathrm{C}=\text { concentration of } \mathrm{Cm}_{2} \mathrm{O}_{3}, \mathrm{~g} / \mathrm{cm}^{3}, \text { and } \\
& \mathrm{T}=\text { temperature, }{ }^{\circ} \mathrm{K} .
\end{aligned}
$$


Table 1. ${ }^{244} \mathrm{Cm}_{2} \mathrm{O}_{3}$ Fuel Properties Being Defined in ORNL Program

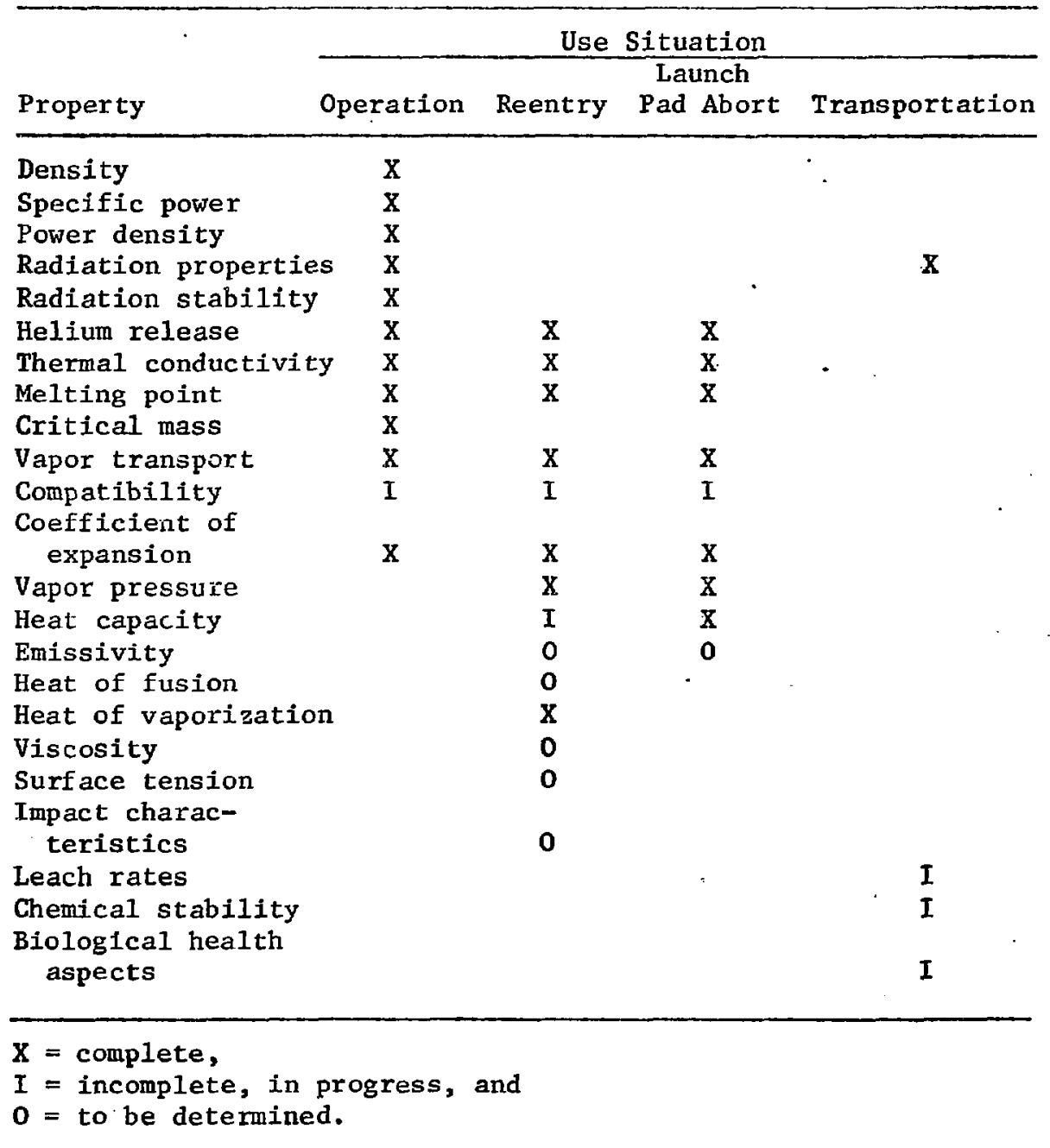




\section{REFERENCE}

1. J. A. Powers, Eugene Lamb, and R. E. Vallee, "Factors Which Influence the Selection of Plutonium-238 and Curium-244 for Space Power Applications", presented at American Nuclear Society Fall Meeting, Miami Beach, Florida, oct. 17-21, 1971. 